\title{
STRENGTHENING THE CAPACITY OF IRRIGATION SCHEMES TO COPE WITH FLOOD THROUGH IMPROVED MAINTENANCE: A COLLABORATIVE APPROACH TO ANALYSE THE CASE OF CHÓKWÈ, MOZAMBIQUE ${ }^{\dagger}$
}

\author{
RAPHAËLLE DUCROT ${ }^{1,5 *}$, MAIRA LEITE $^{2}$, CELINE GENTIL $^{3}$, SAMI BOUARFA $^{4,5}$, DOMINIQUE ROLLIN $^{5,6}$ AND $^{2}$ \\ SEBASTIÃO FAMBA ${ }^{7}$ \\ ${ }^{l}$ CIRAD, UMR G-EAU, Montpellier, France \\ ${ }^{2}$ Universite Montpellier Faculté des Sciences de Montpellier, Montpellier, France \\ ${ }^{3}$ Groupe ESA-Ecole Superieure d'Agriculture d'Angers, Angers, France \\ ${ }^{4} G E A U$ Unit, INRAE, Univ Montpellier, Montpellier, France \\ ${ }^{5}$ IRSTEA, UMR G-EAU, Montpellier, France \\ ${ }^{6}$ Univ Montpellier, Montpellier, France \\ ${ }^{7}$ Universidade Eduardo Mondlane - Faculdade de Agronomia e Engenharia Florestal, Maputo, Mozambique
}

\begin{abstract}
Large-scale irrigation schemes, which are often developed in flood plains, overvalue technical expertise and the control of natural hazards and are particularly vulnerable to flooding, but there has been limited study on the impact of floods on irrigation functioning. Using a transdisciplinary approach developed in the Chokwe Irrigation Scheme during the 2013 post-flood recovery period, we analysed the impact of flooding on the scheme with a focus on maintenance. We argue that the flood crisis provided windows of opportunity to reconsider maintenance procedures by rethinking the relations and responsibilities between actors in this large-scale irrigation scheme; but the robustness of the system can only be increased if the changes strengthen the collective action capacity. Copyright @ 2018 John Wiley \& Sons, Ltd.
\end{abstract}

KEY WORDS: large-scale irrigation; flood resilience; irrigation management transfer; participatory approach

Received 23 June 2017; Revised 23 August 2017; Accepted 9 January 2018

\section{RÉSUMÉ}

Les périmètres irrigués de grande hydraulique qui survalorisent l'expertise technique et le contrôle des risques naturels sont souvent développés dans des plaines d'inondation et donc sont particulièrement vulnérables aux inondations; mais peu de travaux analysent l'impact des inondations sur leur fonctionnement. En s'appuyant sur une approche transdisciplinaire mis en œuvre dans le périmètre irrigué de Chókwè au Mozambique immédiatement après l'inondation de 2013, nous avons analysé l'impact de l'évènement sur le périmètre en s'intéressant tout particulièrement à la maintenance des infrastructures. Nous soutenons que l'inondation a permis de reconsidérer les procédures de maintenance en réorganisant les relations et les responsabilités entre les acteurs de ce périmètre irrigué de grande hydraulique; mais la robustesse du système ne pourra être améliorée que si ces changements conduisent à renforcer les capacités d'action collective. Copyright (c) 2018 John Wiley \& Sons, Ltd.

MOTS CLÉS: grande hydraulique; résilience aux inondations; transfert de l'irrigation; approche participative

*Correspondence to: Dr Raphä̈lle Ducrot, CIRAD Languedoc-Roussillon-Espaces et Sociétés, Rue Jean-François Breton, Montpellier 34398, France. E-mail: raphaele.ducrot@cirad.fr

'Renforcer la capacité des systèmes d'irrigation à faire face aux inondations grâce à une maintenance améliorée: une approche collaborative pour analyser le cas de Chókwè, Mozambique. 


\section{INTRODUCTION}

Because of the substantial investment required by their design, construction and maintenance, the ability of large-scale irrigation schemes to maintain their performance in the long term is a key policy issue. Their capacity to be adapted to a changing environment irrespective of technological shifts, macropolitical economic transformation or climatic change, is crucial. Many such schemes have been developed in flood plains, where the increasing frequency and intensity of rain events result in recurrent floods. While traditional livelihoods of those living on flood plains are adapted to this recurrent risk, the conventional model of large-scale irrigation, which is highly hierarchical, overvalues technical expertise and solutions for the control of natural hazards. Along with other major natural disasters, floods can result in physical damage to infrastructure, thus making the maintenance strategy a key factor in scheme recovery.

For a long time, public institutions have been perceived as the most adequate structures to manage large-scale irrigation systems (Meinzen-Dick, 2007; Ertsen, 2009). From this perspective, the maintenance of irrigation systems is viewed as a set of technical and economic tasks best performed by the centralized bureaucracy in charge of management of the scheme (Murray-Rust et al., 2003). Strong central management-initially associated with control over farmers and the landscape-developed maintenance strategies that were designed to preserve and re-establish the system in order to provide the services expected (Ertsen, 2009). The choice of a given maintenance strategy is dependent on the available budget and the managers' experience and knowledge of the infrastructure, as well as the technical frame of reference of the technicians and managers (Passouant et al., 2009). The chosen strategy directly impacts the hydraulic performance and risk of failure of the system and consequently the scheme's long-term performance.

The policies of irrigation management transfer (IMT) that have become widespread in recent decades strengthened the role of new actors in the maintenance of large-scale public irrigation schemes. With the financial support of international organizations, new responsibilities were assigned to the private sector and water users' associations (WUAs) in the process of maintenance (Merrey and Cook, 2012). Although in practice their effective involvement is variable, it is now widely acknowledged that scheme performance results from the interactions of a variety of actors, including various types of farmers, their associations, and the private sector, as well as heterogeneous agents and segments within the irrigation bureaucracy (Suhardiman et al., 2014).

This new approach reinforces the social and political issues of irrigated scheme management and heightens the importance of considering the relationships between actors.
It highlights the need to consider collective action and horizontal cooperation between actors rather than coerced coordination based on hierarchical procedures (Davies et al., 2004; Meinzen-Dick, 2007).

Consequently maintenance activities cannot be reduced to a technical-economic set of tasks but must be understood as negotiated practices resulting from the interactions between various actors with different individual and professional backgrounds and thus representations. According to Cleaver and De Koning (2015), maintenance practices are thus as much shaped by the technologies and formalized institutions of the scheme, such as maintenance manuals or irrigation regulations, as by existing social norms-social expectations that guide behaviour or the exercise of creative individual agency or individual capacity to act independently. Consequently, it is necessary to rethink maintenance practices in the environmental, social, political and economic constraints and individual representations in which they are embedded.

While there is a considerable literature on adaptation to flooding in urban or rural livelihoods, there have been few studies of the impact of floods on the functioning of irrigation, or on its capacity to recover its properties. Janssen and Anderies (2007) define robustness as the ability of social-technical systems such as irrigation schemes to continue to meet performance objectives in the face of uncertainty and shocks. Floods have often been acknowledged as a major risk in irrigation systems and technical solutions have been incorporated in their design to face this type of hazard. But this design had generally only considered recurrent risks which raises the question of their adaptation to the uncertainties of climate change: unlike risks, uncertainties cannot be statistically characterized (Cardona, 2004; Dessai and Hulme, 2004). Large-scale infrastructures are often perceived as being structurally unable to change and innovate due to lock-in and path dependence (Kay, 2005). Indeed, physical infrastructure alone cannot ensure the necessary flexibility to adapt: the adaptation capacity of socio-technological schemes lies more in the capacity of actors and institutions to deal with uncertainty than in technology (Lam, 2006; Blackmore and Plant, 2008; Milman and Short, 2008). It is now widely acknowledged that the vulnerability of large hydraulic systems is less related to the stability of its physical components (the infrastructure and its design) than to the uncertainty related to the functioning and interactions of its different subsystems (operational, environmental, social political and economic domains). This argues for considering these different domains jointly in the analysis of responses of irrigation schemes to a flood crisis.

Using a transdisciplinary approach developed in the Eau4food project (Froebrich et al., this issue), we analysed the impacts of a flood event on the functioning of the 
Chókwè Irrigation Scheme in Mozambique. This irrigation scheme is regularly affected by flood events and this paper is focused on the recovery period following the flood crisis of January 2013. We drew on the points of view of irrigation scheme managers, non-governmental organizations (NGOs) and public aid organizations and farmers to argue that the flood crisis could provide an opportunity to reconsider maintenance procedures by rethinking the relationships and responsibilities of the actors concerned, as long as the changes introduced do not jeopardize their capacity for collective action.

\section{CONTEXT}

\section{The Chókwè irrigation scheme}

The Chókwè Irrigation Scheme (CIS) was the first irrigated scheme developed in Mozambique and is still the largest scheme in the country, but only 6849 ha were actually irrigated in 2012/2013 due various problems including salinization and the state of the infrastructure. In 2003 it comprised 11971 users of whom $79 \%$ had less than 2 ha, while $64 \%$ of the area was farmed by large and commercial farmers (above 10 ha) (Figure 1). Rice is the main crop during the hot rainy season (October to April) and horticultural crops during the cold dry season (May to September). Official data from the scheme manager, HICEP (Hidráulica de Chókwè, a public company), give an average rice yield that evolved from $3.8 \mathrm{t} \mathrm{ha}^{-1}$ (from 2002 to 2008) to $4.7 \mathrm{t}$ $\mathrm{ha}^{-1}$ afterwards (2009 and 2010,) but surveys found an average yield of $2.1 \mathrm{t} \mathrm{ha}^{-1}$ (Kajisa and Payongayong, 2011) or $2.7 \mathrm{t} \mathrm{ha}^{-1}$ (PROMPAC, 2011). There is no reliable information on horticultural yields.

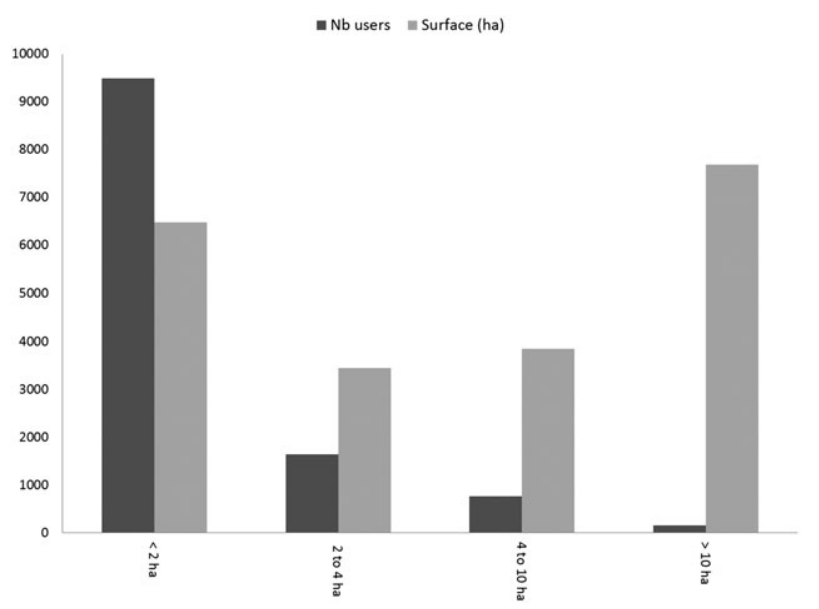

Figure 1. Repartition of the different types of farmers in the Chókwè Irrigation Scheme.
Following the development of an IMT policy sponsored by donors, the Chókwè Irrigation Scheme governance was reviewed in the mid 1990s (Box 1).

Box 1. Organization of the Chókwè Irrigation Scheme for Operation and Maintenance

Operationally, the Chókwè Irrigation Scheme is divided into three sectors: Montante (6000 ha), Sul (19 000 ha) and do Rio (9000 ha). A main canal $14.3 \mathrm{~km}$ long brings water from the Macaretane Dam on the Limpopo River to 3 primary canals, which are themselves divided into 50 secondary canals. Secondary canals are divided into suspended tertiary canals (called locally caleiras). There are 11 primary drains (also called vala) which collect water from secondary canals. Siltation of the canals limits the flow to $11 \mathrm{~m}^{3} \mathrm{~s}^{-1}$ instead of the nominal 43 $\mathrm{m}^{3} \mathrm{~s}^{-1}$, and drainage is made difficult because many secondary drains are heavily silted up and invaded by vegetation (PROMPAC, 2011).

In the 1990s the water sector was reformed: ARASUL, the water agency responsible for river basins in southern Mozambique, is in charge of flood forecasting and operation of the Massingir and Macaretane dams. HICEP, a public firm dependent on the Ministry of Agriculture, was put in charge of the management of the primary infrastructure of the scheme to secure the water supply and distribution, and to collect and manage the water fees. Farmers were organized into 36 water users' associations (WUAs) in charge of the maintenance of the secondary to quaternary infrastructure (irrigation and drainage). The operational maintenance work in the primary network was the responsibility of private service providers contracted by HICEP. To facilitate coordination between these actors, consultative participatory bodies (Conselhos Paritários de Gestão or CPG) were institutionalized in each operational zone with a mandate to meet twice a year for maintenance planning and annual balance of the work. HICEP's annual budget not considering rehabilitation was around US\$ 19 millions in 2013: around 35\% of this sum was allocated maintenance (not considering salaries of permanent staff) (Rizzolio, 2014). Prior to 2008 the water fee was around $20 \mathrm{US} \mathrm{ha}^{-1}$ per season but there is no information on the recovery rate.

Mozambique is the third most exposed country to extreme events on the African continent (Global Facility for Disaster Reduction and Recovery, 2009). The area of the Chókwè Irrigation Scheme, which lies in the inundation plain of the Limpopo River (Figure 2), is particularly vulnerable (Asante et al., 2009) due to the influence of a huge 


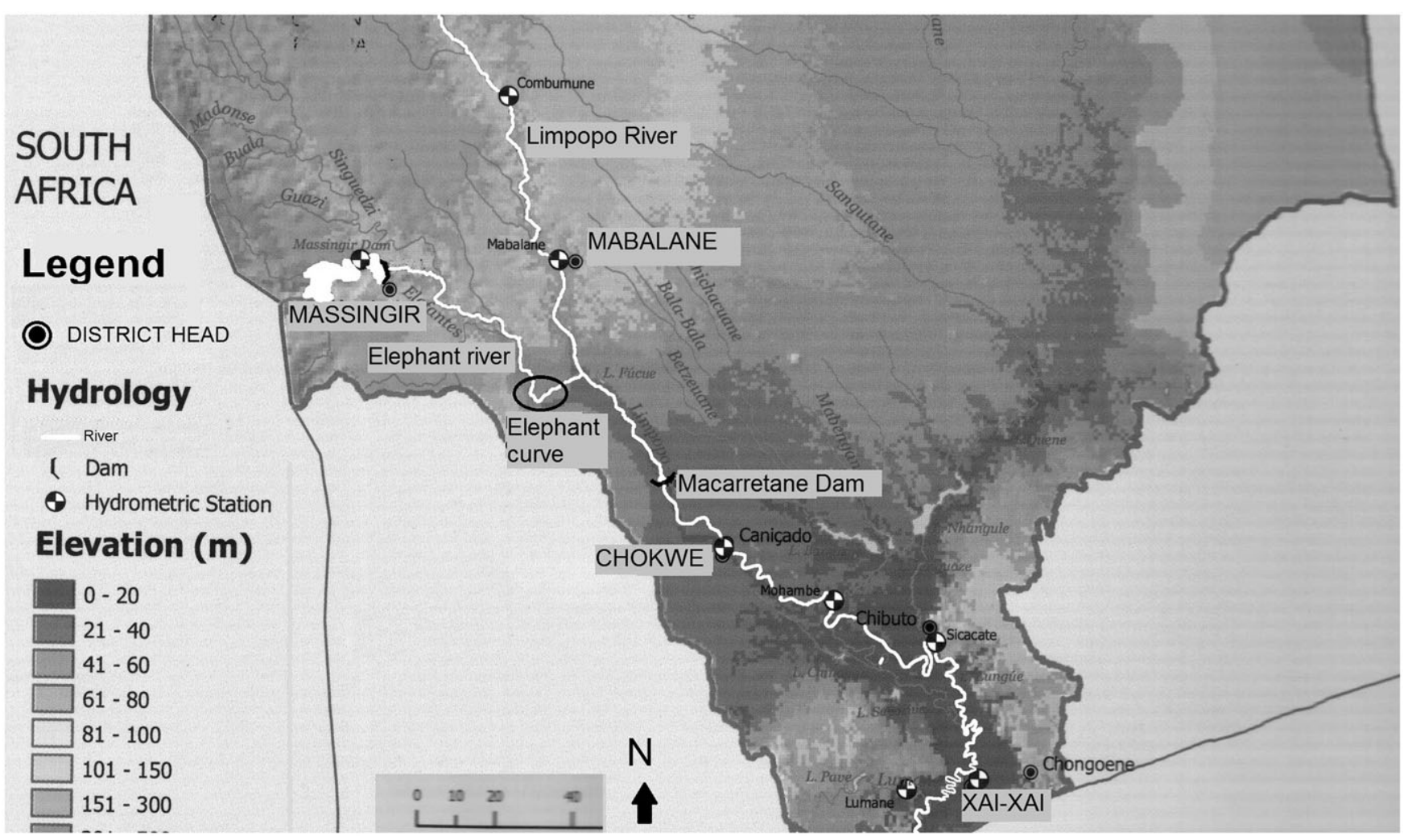

Figure 2. Localization of the Chókwè Irrigation Scheme (adapted from Instituto Nacional de Gestão das Calamidades, 2003).

palaeo-delta in the flood dynamics (Spaliviero et al., 2014). There was no discernible pattern of rain changes in the south of Mozambique between 1960 and 2008 because of the high interannual variability, but the proportion of total rainfall that falls in heavy events is projected to increase during December to February in projections from all models and all scenarios, by up to $18 \%$. It is associated with a projection of an increase of $25 \%$ in the level of peak floods and a small increase in the frequency of floods in the Limpopo Basin (van Logchem and Brito, 2009).

Mild or moderate floods ${ }^{1}$ occurred in half of the 32 years with available data between 1953 and 1994. Four severe floods occurred during this period (Instituto Nacional de Gestão das Calamidades, Universidade Eduardo Mondlane, Famine Early Warning Systems Network, 2003) and two more in 2000 and 2013. During the flood which occurred on 23 January 2013, the city of Chókwè (located in the middle of the scheme), and a part of the scheme and neighbouring districts were flooded; the provincial capital, Xai Xai, suffered the same fate a couple of days later. Although the numbers remained limited compared to the 800 casualties of the 2000 event, the flood left 24 people dead over 2 days and an estimated 150000 people displaced. The flood was described by residents as sudden and massive but the population and technicians were better prepared and forewarned than for the previous event (see supplementary material Box 1 for a description of the flood).

\section{Method}

Our analysis was based on the representations, behaviour, relationships and actions of the actors in the scheme's maintenance. For this purpose, we chose a qualitative, multi-actor and participatory approach, combining focus group discussions (FGDs), participatory mapping and semi-structured interviews that took place shortly after the event, between April and August 2013. Depending on the issue being addressed, separate approaches were adopted with the farmers, technicians and managers of the irrigation scheme and local NGOs involved in post-flood recovery aid (Table I). The participatory flood mapping used, as a discussion basis, the georeferenced maps of each hydraulic sector maintained by HICEP with the infrastructure baseline (primary and secondary infrastructure, roads, etc.). The qualitative data gathered during the participatory mapping exercises were completed with some quantitative data provided afterwards by HICEP staff.

We focused our approach on the relaunch of agricultural activities after the flood. This paper does not address the operational management of the flood on the perimeter or in 
Table I. The research approach following groups of actors.

\begin{tabular}{|c|c|c|c|}
\hline Group & Approaches & What was being investigated & \\
\hline $\begin{array}{l}\text { Irrigation scheme } \\
\text { managers and } \\
\text { technicians }\end{array}$ & $\begin{array}{l}\text { Participatory maps, workshops } \\
\text { and semi-directed interviews } \\
\text { with the main institutions (10) }\end{array}$ & $\begin{array}{l}\text { Organization for infrastructure } \\
\text { management and emergency } \\
\text { interventions. } \\
\text { Flood model and flood } \\
\text { management }\end{array}$ & $\begin{array}{l}\text { Phase } 1 \text {-Interviews with the representatives of the } \\
\text { main institutions concerning their flood experience, } \\
\text { crisis management and damage } \\
\text { Phase } 2 \text {-Workshop of half a day in each irrigation } \\
\text { sector with medium-scale technicians and some } \\
\text { association leaders (10/20 participants): flood } \\
\text { experience, participatory mapping and possible } \\
\text { solutions; digitalization of the information gathered } \\
\text { in the georeferenced maps of HICEP } \\
\text { Phase } 3 \text {-Presentation and discussion of } \\
\text { outcomes with high-level managers ( } 2 \text { workshops) }\end{array}$ \\
\hline $\begin{array}{l}\text { NGOs and public } \\
\text { aid organizations }\end{array}$ & $\begin{array}{l}\text { Semi-directed interviews } \\
\text { ( } 6 \text { institutions and } 6 \text { NGOs) }\end{array}$ & $\begin{array}{l}\text { Information about flood crisis } \\
\text { management, perimeter design } \\
\text { and organization }\end{array}$ & $\begin{array}{l}\text { The interview guidelines contain questions } \\
\text { concerning: (i) the rehabilitation of the scheme; } \\
\text { (ii) flood management; (iii) support for irrigated } \\
\text { agriculture; (iv) local administration representatives } \\
\text { and local leaderships; and (v) NGOs involved in } \\
\text { post-flood relief intervention }\end{array}$ \\
\hline $\begin{array}{l}\text { Farmers } \\
(3 \text { associations } \\
\text { studied) }\end{array}$ & $\begin{array}{l}\text { FGDs and semi-directed } \\
\text { interviews }\end{array}$ & $\begin{array}{l}\text { Perceptions of flood alerts, } \\
\text { reaction and recovery strategy } \\
\text { and innovation }\end{array}$ & $\begin{array}{l}\text { One focus group with each association } \\
\text { ( } 8-15 \text { farmers). Flood maps used as a stimulus for } \\
\text { discussion }\end{array}$ \\
\hline
\end{tabular}

the watershed, the emergency evacuation procedures or the disaster relief operations, although some questions were asked on these procedures to understand how they impacted on individuals as farmers. We worked with the three associations involved in the Eau4Food project and presented in greater detail in the introductory paper.

One person was in charge of the work concerning the participatory mapping. Seven days of work in total were necessary to map the flood dynamic and damage: 3 days of preparation, a 1.5 days for the three workshops in the three hydraulic sectors and 3.5 days to digitalize the information in the HICEP computerized georeferenced database of the scheme. Another facilitator was in charge of the interaction with farmers 'associations and organizations which developed over a 2-month period. Each FGD lasted 2-3 h and was attended by between five and eight farmers. Associations and community leaders were interviewed independently before the FGD.

\section{RESULTS}

\section{The physical impacts of the flood in the scheme}

Mapping the flood. The flood map (Figure 3) clarified the participants' perception concerning: (i) inundated areas in the scheme; (ii) water flow pathways in the scheme; (iii) main infrastructure damage; (iv) areas where water accumulated and drained with difficulty after the flood; (v) emergency repairs to secure minimal water distribution when possible; (vi) emergency interventions before and during the flood to avoid major damage.
They discussed notably the role of the dam and dykes in the protection of the schemes compared to past experience, and the importance of the damage considered as massive by HICEP: $70 \%$ of the irrigated crops were lost (approximately $3000 \mathrm{ha}$ ). HICEP estimated that there were $18 \mathrm{~km}$ of damage along the hydraulic network (39\% in the main canal, $6 \%$ in the primary and $21 \%$ along the secondary canals), including an area that had just been rehabilitated.

In the design of the scheme, different mechanisms were used to limit flood impact in the scheme: two dams were planned (Massingir Dam on the Elephant River completed in 1981 and the Mapai Dam on the Limpopo Branch which was never built), and a series of dykes isolated the scheme from the river. In 2013 the dam faced maintenance problems which limited its flood retention capacity.

The map and discussions highlighted that the primary flow did not surge from the Limpopo River or dyke leakage as expected but from the north-western part of the scheme as the old waterways of the Elephant River were reactivated (Spaliviero et al., 2014). In a second phase dyke failure (through leakage or local overtopping) accentuated the process. The canal systems and the sewage system of the city were both also instrumental in the transfer of flowing water.

The reactivation of the old waterway of the Elephant River in the critical location of the confluence between the Elephant and the Limpopo rivers is a recurrent risk. In 2012, ARA-SUL and HICEP successfully managed to avoid flooding in the city by diverting the flow into a small area in the northern part of the scheme. Small breaches in a dyke were then created to divert the flow back to the river downstream of the intake, but these breaches had not been 


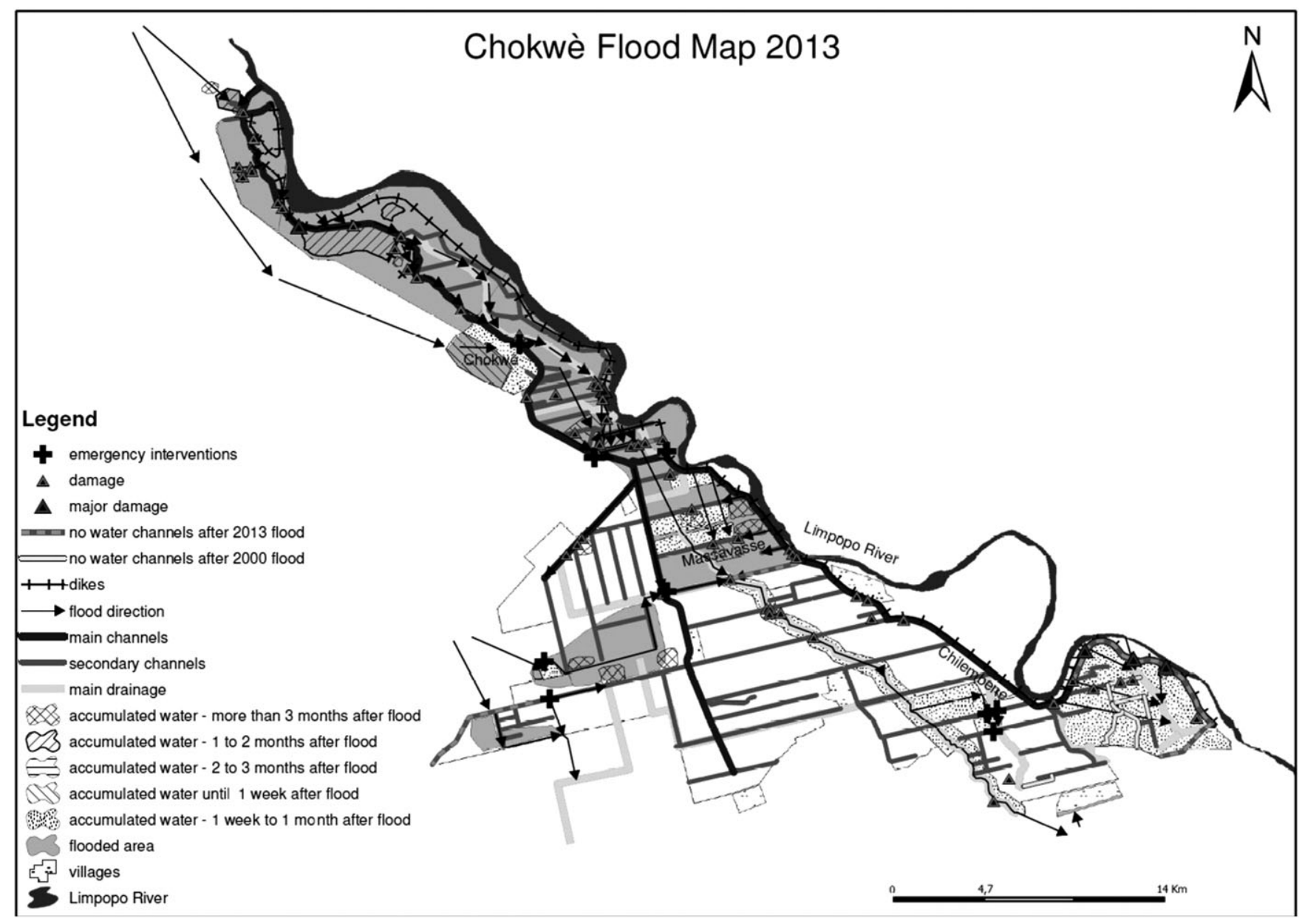

Figure 3. The flood map.

repaired in 2013 for lack of funding. As in the Rhône floods in France (Picon and Allard, 2006), poor maintenance also resulted from confusion concerning the responsibilities and ownership of a dyke system that plays a dual or triple role (river dyke/canal dyke/road) for the institutions in charge of the road, irrigation and watershed infrastructure (Kuijpers et al., 2013). This type of confusion can be traced to difficulties in comprehensively assessing the practical implication of the reforms of water governance initiated in the mid 1990s in many countries, including Mozambique.

The mapping exercise also underlined the role of irrigation and drainage canals in the water flow. This was notably the case of drainage canal $\mathrm{V}$, which had been cleaned just before the flood and proved to be influential in the drainage of the area and city. Certain areas of the scheme were more vulnerable to the consequences of flooding due to their relative proximity to the water's path. The socioorganizational capacity of actors also impacted the extent of local damage. The village of Chilembene, for example, was relatively protected thanks to an initiative of the villagers to break through a canal in order to facilitate drainage. In coordination with the scheme manager, this task was completed after the peak flood by the firm in charge of the rehabilitation to accelerate drainage of the area.

Scheme management at the time of the flood was a source of debate during the mapping exercise. Apparently, the canal gates were closed in an effort to slow down the flooding of the city of Chókwè (and thus facilitate evacuation) and protect the scheme. But as the water came in unexpected volumes, the flood was uncontrollable and the closed gates may have impeded drainage of the water, weakened some of the infrastructure and facilitated inundation of crop areas.

Different types of damage. Table II recapitulates the different types of damage identified during the mapping exercises. They concerned different aspects of the functioning of the scheme (Table II). While some of the damage directly impacted water distribution and/or drainage, other factors had a longer-term impact. According to HICEP, damage 
Table II. Main types of damage observed in the scheme.

\begin{tabular}{|c|c|c|c|}
\hline $\begin{array}{l}\text { Immediate impact on water } \\
\text { distribution }\end{array}$ & $\begin{array}{l}\text { Immediate impact } \\
\text { on water drainage }\end{array}$ & $\begin{array}{l}\text { Long-term impact } \\
\text { on water distribution }\end{array}$ & $\begin{array}{l}\text { Long-term impact } \\
\text { on water drainage }\end{array}$ \\
\hline $\begin{array}{l}\text { - Damage to gates due to debris } \\
\text { - Gates bypass breaking canal banks } \\
\text { - Damage to complex canal } \\
\text { crossing (drainage } \times \text { canal aqueduct) } \\
\text { - Destruction of tertiary suspended } \\
\text { canals (caleiras) } \\
\text { - Erosion of canal banks or rupture } \\
\text { of canal banks (due to floods or } \\
\text { created to accelerate water evacuation) }\end{array}$ & $\begin{array}{l}\text { - Breaches in drainage canals } \\
\text { - Flooding of lower areas which } \\
\text { can take time to disappear due } \\
\text { to soil conditions and saturation }\end{array}$ & $\begin{array}{l}\text { - Modification of canal profile } \\
\text { due to sand deposition and } \\
\text { siltation affecting water } \\
\text { distribution } \\
\text { - Alteration of plot levelling }\end{array}$ & $\begin{array}{l}\text { - Sand deposition in drainage } \\
\text { systems affecting their } \\
\text { drainage capacity }\end{array}$ \\
\hline
\end{tabular}

was estimated at US\$19 million-not including the rehabilitation of the suspended tertiary channels.

\section{The state of the scheme as a consequence of previous flooding in the context of irrigation reform}

The vicious circle of irrigation schemes, which links low payment rate of water fees, inadequate maintenance and poor functioning of infrastructure, and which leads to the dissatisfaction of water users and consequently fuels poor payment rates, is an acknowledged reality of irrigation systems (Inocencio et al., 2007). In the case of Chokwe Irrigation Scheme this vicious circle is accentuated by the frequency of floods which periodically impact plot leveling and canal functionning. This not only exhaust the limited maintenance budget of HICEP but also make rehabilitation a risky investment which discourage donors or private partners from investing in the scheme.

It was only in 1997-10 years after the creation of a Project Implementation Unit to supervise the rehabilitation of the Chókwè Irrigation Scheme-that a first donor, the French Development Agency, agreed to intervene by rehabilitating a pilot area of 1000 ha, along with restructuring of the governance of the scheme. However, the work was delayed because of the 2000 flood: the French funding was then used for post-flood emergency repairs in the scheme while the Japanese government funded the repair of the main canal. Even after this rehabilitation the government of Mozambique (GoM) experienced difficulty mobilizing the traditional donors involved in irrigation development, and the subsequent rehabilitation phases involved unconventional donors such as OPEC (Organization of the Petroleum Exporting Countries) and the Islamic Development Bank.

Two private investors also funded rehabilitation of specific areas. Both were involved in direct production and support to farmers. A British-owned company (Moçfer Industrias Alimentares, MIA) took up irrigated rice production in the CIS in order to make the rice processing facility it had bought in 2005 profitable (Veldwisch, 2015) through direct farming of 500 ha and subcontracting 3500 ha to farmers. More recently, HICEP was also discussing the involvement of a private Chinese consortium (a private firm and a bank) already intervening in another scheme in the province to rehabilitate 10000 ha. Yet, after 4 years of unsatisfactory rice collection MIA decided to stop its activities in the Chókwè Irrigation Scheme mid-2013, a direct consequence of the US $\$ 4$ million of damage its rice stocks and processing facility suffered during the flood. The Chinese bank used the flood vulnerability argument to suspend its support to the consortium. The project is, however, expected to resume with the financial support of the Chinese government.

The rehabilitation projects led by the GoM (in contrast to private-led projects) followed the initial design of the Chókwè Irrigation Scheme up to the complex and fragile aqueducts and tertiary canals. The repairs of the concretesuspended tertiary canals (caleiras) require a large workforce and technical skills for levelling. Some aqueducts were also systematically damaged by floods.

Private rehabilitation has generally been associated with the levelling and transformation of the suspended canals (caleiras) into compacted earth canals, to allow for largescale mechanized cropping systems. The Chinese consortium also wanted to develop a deep drainage system. MIA used five pivots that were destroyed during the 2013 floods. However, no information is available about the rehabilitation and maintenance costs and requirements of these different design options.

The flood risk thus limited the willingness of investors and donors to invest in the scheme, but the full implications of the risk of floods were not really factored into the technical and institutional projects. For example, the first rehabilitation involved the closure of some outlets that facilitated the evacuation of water in the case of flooding, while making use of fragile elevated inlets.

The reform of maintenance governance inspired by IMT policies and the normative view of the scheme's 
functioning had also limited the response capacity of the manager. The internal maintenance unit was broken up and the heavy equipment transferred to service providers that the manager was supposed to contract for preventive, curative and emergency maintenance. The maintenance of the secondary and tertiary infrastructure was supposed to be developed by newly created WUAs that brought farmers together around secondary canals. But HICEP never had the financial resources to contract the service providers. It could only proceed with the manual cleaning of the main canals and the drainage system was ignored. Many WUAs existed only on paper and those that were operational concentrated their efforts on support of crop production (for example, hiring tractors for mechanized labour) rather than coordinating local infrastructure operation and maintenance as required by the newly established regulations. Their intervention capacity was in any case limited: they had no funding source, while the size of some of the infrastructure and the amount of sand deposited during flooding require the mobilization of heavy machinery. The other institutions such as the coordinating platform for maintenance (Conselho Paritario de Gestão) never really met after the departure of the French rehabilitation team.

\section{The flood as a mediating event which attracted increased donor attention}

In 2008, the state authorized the creation of a maintenance unit within HICEP and donated excavators and bulldozers. In 2013 HICEP was able to proceed with some emergency repairs immediately after the flood, in order to avoid the loss of some of the rice that had withstood submersion. HICEP managed to get water back into the primary canal and to recover a water service over 4000 ha only a month after the flood, a performance for which it was justifiably praised. By comparison, it had taken 2 years to achieve the same result in 2000 because the manager was obliged to subcontract the work (see supplementary material Table 2 for the evolution of the area cropped and/or harvested between 1998 and 2014).

The flood also highlighted the importance of good maintenance of drainage canals for the urbanized areas, highlighted by the role of drainage canal V. The displacement of 50000 people from the area due to the flooding also attracted media and government attention to the area. This enabled an increase in the donation of equipment first for emergency work and then for more permanent maintenance and the functioning of the maintenance unit, which amounted to 18 machines including 5 excavators. Although this remained far below the equipment level of the manager before the reform (see supplementary material Table 1), the maintenance unit is now steadily developing, which has improved the maintenance of the drainage system.

\section{Impact on the relationships between actors}

A new dynamism centred on the HICEP maintenance unit. The success of the emergency activities and the increase in their maintenance capacity provided the manager with a sense of agency, which along with other factors such as government support created a new dynamism in the maintenance strategy and reinforced its capacity for action. The relationships between actors were also reconfigurated by the flood (see supplementary materials Figure 1 and 2 for an illustration of this reconfiguration). The sharing of responsibilities between WUAs and HICEP was renegotiated in parallel, and HICEP is now officially in charge of the maintenance of primary and secondary canals and the repairs of the suspended canals (tertiary) when the latter break down. For their part, farmers agreed to a $50 \%$ increase in the water fee and the creation in 2014 of an infrastructure fee currently only charged in the rehabilitated Rio sector. Finally, the Participatory Management Councils (Conselhos Paritario de Gestão) were (re)activated and meeting frequency increased from two to six a year. Some confusion remained about the role and place of the farmers associations ${ }^{2}$ in the scheme that existed before the creation of WUAs.

\section{Farmer initiatives for infrastructure maintenance.} Although WUAs had been created for maintenance purposes, they were mostly perceived as instruments to capture and allocate external support. They had little experience of mobilization for collective action, except in one women's association which pre-existed WUA creation (UNAC association). Immediately after the flood, many farmers organized themselves to repair the tertiary infrastructure and irrigate where secondary canals were still functional. Collective initiatives were mentioned in the three FGDs. They included joining forces to repair fallen caleiras, buying cement for repairs, collective cleaning of secondary and tertiary canals to save the rice crops that survived submersion and creating a collective nursery for horticultural crops. Some individual innovative practices were also observed, such as using plastic tubes to replace caleiras or building earth canals. Some farmers or associations also bought fuel to secure the intervention of HICEP heavy equipment in their area.

However, the number of farmers involved in each initiative as well as social pressure for mobilization appeared limited. Except for the women's association already mentioned, mobilization resulted more from the authority of village leaders than association functioning. They were also hampered by different limitations. Groups of women, who form the majority of small-scale farmers, often lack the strength to carry out repairs of heavy caleiras. The levelling of caleiras is acknowledged by all actors to be a difficult and 
technical task, and when inappropriately carried out can result in significant water loss, accentuating short- or medium-term drainage and salinization issues. Moreover, previous studies on the generalization of alternative designs for caleiras had underlined the need to associate them with pumping, which would increase operational and maintenance costs. Many technicians were thus uncomfortable with these initiatives. But the main limits remained the money shortage that characterized the emergency phase and the difficulties experienced in buying necessary materials. Farmers were unable to fund major repairs or clean silted secondary or even tertiary drainage canals, all of which require heavy machinery.
Increasing tensions due to transparency issues in flood-relief mechanisms for agriculture. Although farmers in the area do not perceive flooding as a problem but rather an opportunity which increases soil fertility and enables productive recession crops, relief aid was necessary for many farmers in order to start the new agricultural cycle as they had lost their food reserves and assets for their livelihoods.

A large variety of organizations and institutions were active in the district at this stage. Each of them had their own geographic and/or social targets, philosophy and mode of intervention (Table III). A majority of organizations provided seeds or cuttings but there were limited options

Table III. Examples of different types of intervention in support of agricultural production in the recovery phase.

OXFAM Agriculture fair and voucher distribution to targeted families

$\mathrm{CPL}^{\mathrm{a}}$

Allocation of a beneficial credit advantageous to a limited number of farmers

$\mathrm{SDAE}^{\mathrm{b}} \quad$ Recovery kit distribution in all villages
As one of the NGOs involved in post-flood relief interventions under the coordination of INGC, OXFAM was assigned the district area of Chókwè. In the nine communities selected by the $\mathrm{NGO}$, it provided support for the rehabilitation of the domestic water supply system and for agricultural production for food security. A subsidy worth 2500 MT in the form of voucher to spend at an agriculture fair organized by the NGO was provided to the target population (4490 families) using a well-defined methodology to select the families. Recipients could choose to buy a wide range of different (agricultural) inputs (seeds, small equipment, fertilizers, etc). The seed quality was assessed to be of a high standard. The whole process was assessed afterwards. The GoM gave 19800000 MT to HICEP to fund an advantageous credit line (10\% interest rate instead of the usual $36 \%$, 6-month non-payment period, 1-year delay to repay, applicable to any type of crop) for the new agriculture cycle in the scheme. HICEP contracted the management of this fund to the credit organization it controlled (CPL).

The selection of recipients was unclear: half of the recipients were supposed to be big farmers so that the credit could serve to increase food supply availability in markets. The other half targeted small and medium-sized farmers. Leaders' associations were asked to provide a list of names with the requested amounts. The aggregated demand was 15 times the available amount and HICEP and CPL made a second selection, involving 250 farmers in total (4 or 5 persons per association). The limited number of beneficiaries and the lack of transparency in the selection process caused a great deal of frustration.

The agriculture extension services distributed seeds (cabbage, maize, peas, onion, lettuce and tomato) and small equipment on behalf of the government and international agencies (FAO). The recipients were associations and various villages. Distribution followed traditional administrative mechanisms: allocation by administrative post, then localities and finally villages. Elected leaders were in charge of the distribution at village level. The farmers had no choice of seeds and received a limited quantity (if any at all) as there was a large deficit compared to the demand for maize, onions and tomatoes. Some associations were forgotten in the distribution list. The seed quality was assessed as poor.

Sources: Field interviews; Simpson et al., (2013).

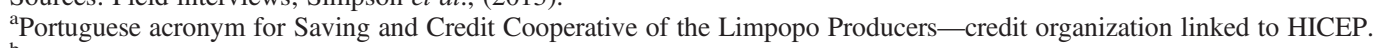

${ }^{\mathrm{b}}$ Portuguese acronym for District Services of Agriculture and Economic Affairs which gathers together government extension services at district level. 
for credit or agricultural inputs. Many farmers complained of the difficulty of getting information on the different options and of gaining access to a scheme. They were particularly critical of the limited number of packages made available at each village level, the quantity available per family as well as the seed quality of the government packages. The lack of transparency of many of the distribution schemes was a recurrent complaint of all discussions and interviews. The frustration was particularly acute concerning the allocation of the credit line for irrigation due to the very limited number of people concerned and the expectations raised during the identification phase.

\section{DISCUSSION AND CONCLUSION}

The new dynamism of the maintenance unit addressing the drainage issue in the scheme

At policy level, irrigation schemes in flood plains are often considered only as investment to control water for agricultural intensification. Consequently floods are considered as externalities and not part of the system. Focusing on economic efficiency and reduction of state involvement (and spending), the IMT policy reform limited the capacity for action of the scheme manager to react to emergency situations. The 2013 flood event highlighted the role of the scheme's drainage systems, especially important in densely populated areas (Ladki et al., 2006) but which are generally disregarded at policy level (Abdeldayem et al., 2005; Ritzema et al., 2007) . The intensification of agriculture enabled by irrigation is accompanied by the development of various economic activities around input supply or value chains, which make these areas attractive for the population. Thanks to the recent effort to better mainstream climate change adaptation into development assistance (Sietz et al., 2011), floods in the Limpopo Basin are now widely acknowledged as the norms and not the exception. In this context, the capacity of the scheme manager to address a flood crisis as well as regular maintenance of the drainage system is thus not only a food production necessity but also contributes to population safety and well-being. This is all the more important as traditional prevention solutions involve many limitations, as underlined by the 2013 flood: both the Massingir Dam and the dyke system that were supposed to protect the city faced maintenance issues and the reallocation strategy failed due to issues of cost and accessibility (Artur and Hilhorst, 2012).

The 2013 flood was thus an opportunity for the manager to learn and improve the management process. The ability to recover irrigation for $50 \%$ of the surface cultivated before the flood in less than 2 months led to the remobilization of technicians and agents. The flood was also instrumental in redynamizing HICEP's maintenance strategy. It not only helped redefine and validate HICEP's responsibility for the irrigation canals by the state but also helped to channel funding for the reinforcement of the manager's maintenance unit and rehabilitation of the dykes. The (re)allocation of heavy machinery enabled work to start on cleaning the scheme's drainage system, which had been neglected over the previous 15 years.

But the capacity for response and action goes beyond the development of a sense of agency and presupposes certain levels of skills, equipment and budget. It also presupposes the capacity to make suitable decisions, which is related to access to information and learning from previous experience, as well as coordination of the various actions and reactions of the actors.

\section{Strengthening the availability of information to better manage flood situations}

The question of the flood safety of hydraulic infrastructure has been raised mainly in regard to dykes, dam management and more recently urban drainage systems (Vis et al., 2003; Berry et al., 2013). At international level there is still little investigation of how to manage complex water conveyance networks in the case of flood events. The flood map was a way to quickly collect and synthesize different expertise and local knowledge and them in a single digitalized document. The confrontation of multiple local knowledges partially balances the risk of inaccuracy due to mobilization of representations. The final map was used by HICEP in at least one meeting with donors to present synthesized information about the flood and highlight post-flood activities.

It was also a first step towards building the institutional memory necessary to improve response procedures (Harris and Bahadur, 2011; Throness, 2013) which is poor in many local institutions, due to high staff rotation and the limited availability of up-to-date technical information-such as accurate maps (Kuijpers et al., 2013). In particular, it was impossible to find spatialized information concerning the impact of the 2000 flood on the scheme: comparing the 2000 and 2013 flood events could potentially help identify fragile sections of the infrastructure that should receive specific attention, and thus propose and discuss technical amelioration. The map could also be valuable in identifying the most important drainage issues in the scheme, by comparing this knowledge-based map with the post-flood map provided by satellite image analysis (UNITAR/UNOSAT, 2013, https://unosat-maps.web.cern.ch/ unosat-maps/MZ/FL2013000018MOZ/UNOSAT_A3_RS_ FL20130121MOZ_ChokweFlood_4Feb.pdf).

A second step could be to add a sheet for each emergency activity, summarizing the type of intervention, the resources mobilized (equipment, workforce, money), the duration 
of the work and the difficulties encountered. This would provide useful information for further flood contingency planning. The cost-benefit analysis of the rehabilitation design option could also be complemented by the investment cost of the various design options of the tertiary systems, including those developed in private areas, as well as their maintenance and repair costs, but also their potential impact on long-term drainage and salinization. This is typical research development work that could be undertaken in collaboration with local universities.

\section{Strengthening collective capacity for action}

In farmer-managed irrigation systems in Nepal, the major disturbances were not so much those affecting the physical part of the system such as floods or landslides, but the changes in user-group composition, or those affecting the institutional structure (Ternström, 2005). This tends to indicate that social and collective relationships play a more important role in the adaptive capacity of hydraulic systems than technical aspects.

Social learning activities are being promoted as a way to develop adaptive and collective action by enhancing individual capacity and collective learning as well as facilitating group coherence and dynamism (Maurel et al., 2007; Reed et al., 2010). The mapping exercise, a typical social learning activity, was an opportunity for all the local technical staff of the irrigation sectors to collectively discuss the event, its causes and the actions taken and to analyse their consequences while trying to organize the spatial coherence of these impacts at sector and then scheme level. It contributed to the capacity building of lower-level staff in map reading and spatial analysis, which can be useful in maintenance planning. They were also encouraged to present their perspectives, which they had limited opportunity to do in the prevailing hierarchical setting of HICEP. Such social learning activities can help the different actors rethink their task and responsibilities. However, the exercise did not mobilize farmers, although in fact such an exercise could have been valuable for reinforcement of the participatory maintenance platforms, which at the time were inoperative.

HICEP acknowledges that the real engagement of farmers is necessary for long-term sustainability of the scheme, not only through the payment of the water fee but also via regular maintenance of the tertiary level. In the scheme, collective actions and initiatives around maintenance are limited. Most associations focus on agricultural support and have limited effective action in terms of maintenance and water distribution. The flood crisis proved to be a key moment where collective actions developed spontaneously which could be used to improve WUA capacity and involvement in the functioning of the scheme. This should involve activities in the form of training and the accompaniment of farmers both during the regular maintenance of the tertiary canals and emergency repairs.

The renewed central focus on maintenance was complemented by the new attention paid to the formalized relationships between the managers and farmers' associations and a review of the formal maintenance institutions. These improved communications between the manager and the leaders of WUAs. But the impact on collective action was limited for two reasons: in practice there appears to be tension between a willingness to encourage greater farmer involvement and the entrenched attitudes of command and control. Furthermore, a lack of transparency and confusion in the distribution of agricultural support during the recovery phase have increased mistrust between small-scale farmers and the decision-level layer made up of association leaders and technicians, which is perceived as favouring only some farmers. This could jeopardize collective engagement and directly affects the maintenance of infrastructure as underlined in the recent case of borehole maintenance in an upstream district (Ducrot, 2017). Improving communication and farmers' participation in maintenance planning could be a starting point in improving trust between actors, provided technicians take care to include small-scale farmers' perspectives better in the process.

Recurrent flooding — and poor maintenance-had directly impacted the productivity of crop system in the Chókwè Irrigation Scheme. The new dynamism in addressing the drainage issue-combining both technical and social aspects-is an opportunity to break the vicious circle into which the Chókwè Irrigation Scheme has been locked over the last 40 years.

\section{ACKNOWLEDGMENTS}

This study was part of the EU FP7-KBBE research project Eau4Food. We would like to thank HICEP and the farmers' associations for their participation in the study. We are particularly grateful to Dr Soares Xerinda, president of the board of HICEP, for his careful reading of this paper and his suggestions, as well as to Ing Taelane, Benguine and Cossa from HICEP for the information they provided.

\section{NOTES}

1 Mild or moderate flood corresponds to a water level in the Limpopo River of 4-8 $\mathrm{m}$ in Chókwè, while a severe flood is above $8 \mathrm{~m}$.

2 These associations are members of UNAC (National Union of Small Scale Irrigators), while WUAs are grouped in UNAR (National Union of Irrigators). 


\section{REFERENCES}

Abdeldayem S, Hoevenaars J, Mollinga PP, Scheumann W, Lootweg R, Steenbergen FV. 2005. Agricultural drainage: towards an integrated approach. Irrigation and Drainage Systems 19: 71-87. https://doi.org/ 10.1002/ird.344.

Artur L, Hilhorst D. 2012. Everyday realities of climate change adaptation in Mozambique. Global Environmental Change 22: 529-536. https://doi. org/10.1016/j.gloenvcha.2011.11.013.

Asante K, Brito R, Brundrit G, Epstein P, Fernandes A, Marques MR, Mavume A, Metzger M, Patt A, Queface A, Sanchez del Valle R, Tadross M. 2009. Main Report. INGC Climate Change Report: Study on the Impact of Climate Change on Disaster Risk in Mozambique. Instituto Nacional de Gestão das Calamidades: Maputo, Mozambique.

Berry G, Richard A, Assela P, Chris Z. 2013. Climate change uncertainty: building flexibility into water and flood risk infrastructure. Climatic Change 116(2): 411-423.

Blackmore JM, Plant RAJ. 2008. Risk and resilience to enhance sustainability with application to urban water systems. Journal of Water Resources Planning and Management ASCE 134(3): 224-233. https:// doi.org/10.1061/\%20ASCE\%200733-9496\%202008\%20134:\%203\% 20224.

Cardona OD. 2004. The need for rethinking the concepts of vulnerability and risk from a holistic perspective: a necessary review and criticism for effective risk management. In Disasters, Development and People, Bankoff G, Frerks G, Hilhorst D (eds). Earthscan Publishers: London.

Cleaver FD, De Koning J. 2015. Furthering critical institutionalism. International Journal of the Commons 9(1): 1-18.

Davies B, Blackstock K, Brown K, Shannon P. 2004. Challenges in creating local agri-environmental cooperation action amongst farmers and other stakeholders. The Macaulay Institute: Aberdeen.

Dessai S, Hulme M. 2004. Does climate adaptation policy need probabilities? Climate Policy 4: 107-128.

Ducrot R. 2017. When good practices by water committees are not relevant: Sustainability of small water infrastructures in semi-arid Mozambique. Physics and Chemistry of the Earth, Parts A/B/C 102: 59-69.

Ertsen MW. 2009. From central control to service delivery? Reflections on irrigation management and expertise. Irrigation and Drainage 58(S1): S87-S103.

Global Facility for Disaster Reduction and Recovery. 2009. Disaster Risk Management Programs for Priority Countries. World Bank: Washington, DC. (C) World Bank. available at: https://openknowledge. worldbank.org/handle/10986/22826 License: CC BY 3.0 IGO.

Harris K, Bahadur A. 2011. Harnessing Synergies: Mainstreaming Climate Change Adaptation in Disaster Risk Reduction Programmes and Policies. IDS: Brighton.

Inocencio $\mathrm{AB}$, Kikuchi $\mathrm{M}$, Tonosaki M, Maruyama A, Merrey D, Sally H, de Jong I. 2007. Costs and Performance of Irrigation Projects: a Comparison of Sub-Saharan Africa and Other Developing Regions. International Water Management Institute: Colombo, Sri Lanka.

Instituto Nacional de Gestão das Calamidades, Universidade Eduardo Mondlane, Famine Early Warning Systems Network (INGC, UEM, FEWSNET). 2003. Atlas for Disaster Preparedness and Response in the Limpopo Basin.

Janssen MA, Anderies JM. 2007. Robustness trade-offs in social-ecological systems. International Journal of the Commons 1(1): 43-66.

Kajisa K, Payongayong E. 2011. Potential of and constraints to the rice Green Revolution in Mozambique: A case study of the Chokwe irrigation scheme. Food Policy 36(5): 615-626.

Kay A. 2005. A critique of the use of path dependency in policy studies. Public Administration 83(3): 553-571.
Kuijpers A, Sonneville JLJd, Vaz AC, Karsten H. 2013. Scoping Mission on Technical Assistance for Flood Recovery in Mozambique. Ministry of Public Works and Housing, National Directorate of Water: Maputo, Mozambique; $48 \mathrm{pp}$.

Ladki M, Faysse N, Vega D, PeÑarrieta R, Bechard M. 2006. L'urbanisation des périmètres irrigués: problèmes, opportunités et choix difficiles. Leçons tirées des expériences française et bolivienne. In L'avenir de l'agriculture irriguée en Méditerranée Nouveaux arrangements institutionnels pour une gestion de la demande en eau. Cahors, France, HAL ID: cirad-00191053 https://hal.cirad.fr/cirad00191053.

Lam WF. 2006. Foundations of a robust social-ecological system: irrigation institutions in Taiwan. Journal of Institutional Economics 2(02): 203-226.

Maurel P, Craps M, Cernesson F, Raymond R, Valkering P, Ferrand N. 2007. Concepts and methods for analysing the role of information and communication tools (IC-tools) in social learning processes for river basin management. Environmental Modelling and Software 22: 630-639 https://doi.org/10.1016/j.envsoft.2005.12.016.

Meinzen-Dick R. 2007. Beyond panaceas in water institutions. Proceedings of the National Academy of Sciences 104(39): 15200-15205.

Merrey DJ, Cook S. 2012. Fostering institutional creativity at multiple levels: towards facilitated institutional bricolage. Water Alternatives 5(1): $1-19$.

Milman A, Short A. 2008. Incorporating resilience into sustainability indicators: an example for the urban water sector. Global Environmental Change 18: 758-767.

Murray-Rust DH, Svendsen M, Burton M, Molden DJ. 2003. Irrigation and drainage systems maintenance: needs for research and action. Irrigation and Drainage Systems 17(1-2): 129-140. https://doi.org/10.1023/ A:1024952818884.

Passouant M, Le Gal P-Y, Keita B. 2009. The contribution of information systems in maintaining large-scale irrigation schemes. Irrigation and Drainage Systems 59(3): 241-253 https://doi.org/10.1002/ird.469.

Picon B, Allard P. 2006. Gestion du risque inondation et changement social dans le delta du Rhône: les" catastrophes" de 1856 et 1993-1994. Editions Quae: Paris, France.

Project for Rice Productivity Improvement in Chokwe Irrigation Scheme (PROMPAC). 2011. Baseline survey. Japanese International Cooperation Agency. 47 pp.

Reed MS, Evely AC, Cundill G, Fazey I, Glass J, Laing A, Newig J, Parrish B, Prell C, Raymond C, Stringer LC. 2010. What is social learning? Ecology and Society 15(4): r1.

Ritzema HP, Wolters W, Bhutta MN, Gupta SK, Abdel-Dayem S. 2007. The added value of research on drainage in irrigated agriculture. Irrigation and Drainage 56: S205-S215. https://doi.org/10.1002/ird.337.

Rizzolio MD. 2014. Maintenance et drainage: Développement et test d'un instrument de discussion sur la gestion du périmètre irrigué de Chókwè. Département des Sciences de la Terre, de l'Eau et de l'Environnement. Université de Montpellier II: Montpellier, France; 67 pp. Thèse de Master 2

Sietz D, Boschütz M, Klein RJT. 2011. Mainstreaming climate adaptation into development assistance: rationale, institutional barriers and opportunities in Mozambique. Environmental Science \& Policy 14(4): 493-502. https://doi.org/10.1016/j.envsci.2011.01.001.

Simpson R, Sutton T, Ngwenya D. 2013. Evaluation of the 'Gaza Flood Response, Mozambique 2013'. Oxfam International; 20 pp.

Spaliviero M, Dapper MD, Maló S. 2014. Flood analysis of the Limpopo River basin through past evolution reconstruction and a geomorphological approach. Natural Hazards and Earth System Sciences 14: 2027-2039. https://doi.org/10.5194/nhess-14-2027-2014.

Suhardiman D, Giordano M, Rap E, Wegerich K. 2014. Bureaucratic reform in irrigation: a review of four case studies. Water Alternatives 7(3): $442-463$. 
Ternström I. 2005. Adaptation to disturbances in common-pool resource management systems. Beijer Discussion Paper Series. Stockholm, Sweden. Throness B. 2013. Keeping the memory alive, preventing memory loss that contributes to process safety events. Process Safety Progress 33(2): 115-123. https://doi.org/10.1002/prs.11635.

van Logchem B, Brito R. 2009. Synthesis Report: INGC Climate Change Report: Study on the Impact of Climate Change on Disaster Risk In Mozambique. Instituto Nacional de Gestão das Calamidades: Maputo, Mozambique; $57 \mathrm{pp}$.

Veldwisch GJ. 2015. Contract farming and the reorganisation of agricultural production within the Chókwè Irrigation System, Mozambique. The Journal of Peasant Studies 42(5): 1003-1028.
Vis M, Klijn F, De Bruijn KM, Van Buuren M. 2003. Resilience strategies for flood risk management in the Netherlands. International Journal of River Basin Management 1(1): 33-40. https://doi.org/10.1080/ 15715124.2003.9635190.

\section{SUPPORTING INFORMATION}

Additional supporting information may be found in the online version of this article at publisher's web site. 